\title{
Analisis Mengenai Dampak Lingkungan Paket Pelebaran Jalan RTA Milono Palangkaraya
}

\author{
Anwar Muda \\ Balai Besar Pelaksanaan Jalan Nasional VII \\ Kementerian Pekerjaan Umum dan Perumahan Rakyat Palangka Raya
}

\begin{abstract}
ABSTRAK
Setiap kegiatan pembangunan yang dilaksanakan pasti menimbulkan dampak terhadap lingkungan baik dampak positif maupun dampak negatif. Untuk itu perlu diperhatikan bagaimana melaksanakan pembangunan untuk mendapatkan hasil dan manfaat yang maksimum dengan dampak negatif terhadap lingkungan yang minimum. Penelitian ini bertujuan untuk mengetahui bagian-bagian kajian AMDAL dan permasalahan AMDAL pada Paket Pelebaran Jalan RTA Milono Palangka Raya serta cara penanggulangannya. Hasil penelitian menunjukkan, bahwa kegiatan yang dikaji dari aspek kelayakan lingkungan disebut berwawasan lingkungan. Untuk mencapai hal tersebut diperlukan adanya Analisis Mengenai Dampak Lingkungan. Analisis Mengenai Dampak Lingkungan adalah salah satu instrumen yang sifatnya formal dan wajib bagi kegiatan-kegiatan yang kemungkinan akan menimbulkan dampak besar dari penting terhadap lingkungan hidup. Berdasarkan hasil penelitian ini, maka disarankan untuk pencegahan terjadinya kebisingan, agar mengikuti aturan yang ada seperti peredam suara. Kemudian membuat aturan atau sanksi dalam menjalankan AMDAL sehingga diharapkan dapat meminimalisir dampak lingkungan.
\end{abstract}

Kata kunci : analisis, dampak lingkungan, pelebaran, jalan.

\section{PENDAHULUAN}

Pembangunan infrastruktur jalan dan jembatan bertujuan untuk mendukung distribusi lalu lintas barang maupun manusia dan membentuk struktur ruang wilayah (Renstra Kementerian PU 2010-2014,2010), sehingga pembangunan infrastruktur memiliki 2 (dua) sisi yaitu tujuan pembangunan dan dampak pembangunan. Setiap kegiatan pembangunan yang dilaksanakan pasti menimbulkan dampak terhadap lingkungan, baik dampak positif maupun dampak negatif, yang perlu diperhatikan adalah bagaimana melaksanakan pembangunan untuk mendapatkan hasil dan manfaat yang maksimum dengan dampak negatif terhadap lingkungan yang minimum.

Sedangkan pemerintah telah banyak mengeluarkan peraturan dan pedoman yang mengatur masalah pembangunan jalan dan jembatan yang berwawasan lingkungan, Dalam implementasi di lapangan peraturan dan pedoman tersebut telah dimasukkan dalam pasal syarat-syarat kontrak, sehingga kontraktor sebagai penyedia jasa wajib melaksanakan pasal-pasal tersebut.

Pada GBHN menyebutkan bahwa : "Bangsa Indonesia menghendaki hubungan selaras antara manusia dengan Tuhan, dan antara manusia dengan lingkungan alam sekitarnya". Dengan demikian perlu adanya usaha agar hubungan manusia Indonesia dengan lingkungan semakin serasi. Sebagai modal dasar, sumberdaya alam harus dimanfaatkan sebaik-baiknya, oleh karena itu harus selalu diupayakan agar kerusakan lingkungan sekecil mungkin. Hal ini dapat terjadi apabila analisis mengenai dampak 
lingkungan diterapkan pada setiap kegiatan yang diperkirakan mempunyai dampak penting terhadap lingkungan.

Masalah lingkungan hidup di Indonesia diawali oleh seminar tentang "Pengelolaan Lingkungan Hidup dan Pembangunan Nasional" yang diselenggarakan oleh Universitas Padjajaran di Bandung pada tahun 1972. Para Sarjana dan ahli Indonesia sudah lama mengikuti perkembangan masalah lingkungan, namun Pemerintah Indonesia baru mengenal masalah lingkungan secara resmi sejak mengikuti sidang khusus PBB tentang lingkungan hidup di Stockholm 5 Juni 1972.

Beberapa tinjauan pustaka berikut menunjukkan hasil penelitian tentang hal tersebut. Ana Shoba (2006) melakukan penelitian Tesis bidang Ilmu Lingkungan Program Pascasarjana Universitas Diponegoro yang berjudul Evaluasi Pelaksanaan Pengelolaan dan Pemantauan Lingkungan Pada Beberapa Industri di Kabupaten Tangerang. Dimana penelitian Tesisnya tersebut bertujuan untuk mengkaji sejauh mana implementasi rencana pengelolaan dan pemantauan lingkungan, faktor-faktor penyebab industri tidak melaksanakan rencana pengelolaan lingkungan, gambaran keterlibatan masyarakat dalam pelaksanaan pengelolaan dan pemantauan lingkungan serta pengawasan pelaksanaan yang dilakukan oleh dinas/instansi terkait.

Hasil penelitiannya menunjukkan, bahwa berdasarkan evaluasi dan kajian terhadap 6 sampel terpilih ditemukan bahwa (1) pelaksanaan pengelolaan dan pemantauan lingkungan yang dilakukan oleh industri belum mengarah pada kesadaran kelestarian lingkungan, (2) hal ini masih menjadi beban dan belum dirasakan manfaatnya oleh industri, (3) pengelolaan dan pemantauan lingkungan dilaksanakan untuk mencegah gejolak masyarakat (4) keterlibatan masyarakat masih relatif rendah disebabkan kurangnya pengetahuan masyarakat (5) dan juga tidak adanya akses bagi masyarakat yang ingin terlibat dalam pengelolaan dan pemantauan lingkungan, (6) pengawasan yang dilakukan masih bersifat pasif dan reaktif, (7) koordinasi dengan instansi terkait yang kurang terpadu, (8) penerapan reward and punishment belum dilaksanakan.

Nunung Prihatining Tias (2009) melakukan penelitian Tesis bidang Ilmu Lingkungan Program Pascasarjana Universitas Diponegoro yang berjudul Efektivitas Pelaksanaan Amdal dan UKL UPL Dalam Pengelolaan Lingkungan Hidup di Kabupaten Kudus. Dalam penelitian Tesisnya tersebut bertujuan untuk mengidentifikasi dan mengevaluasi pelaksanaan AMDAL dan UKL UPL pada perusahaan yang sudah memiliki dokumen lingkungan, gambaran keterlibatan masyarakat dalam mendukung pengelolaan lingkungan serta pengawasan yang dilakukan oleh pemerintah daerah.

Hasil penelitiannya menunjukkan bahwa (1.) Pelaksanaan pengelolaaaan dan pemantauan lingkungan yang dilakukan pada masing-masing kegiatan masih pada tahap pengelolaan limbah yang dihasilkan belum mengarah pada kesadaran untuk melestarikan lingkungan (2.) Pelaku kegiatan usaha masih menganggap bahwa kewajiban untuk mengimplementasikan pengelolaan dan pemantauan ligkungan masih merupakan beban yang memberatkan dari segi biaya, dan pihak pengusaha belum merasakan keuntungan secara langsung dari kegiatan pengelolaan dan pemantauan lingkungan yang telah dilakukan (3.) Keterlibatan dan kepedulian masyarakat di sekitar lokasi kegiatan terhadap pelaksanaan pengelolaan dan pemantauan lingkungan yang dilakukan relatif masih rendah, masyarakat masih berangggapan bahwa kegiatan usaha yang banyak memberikan bantuan dan menyerap banyak tenaga kerja lokal merupakan kegiatan usaha yang telah peduli terhadap lingkungan. Masyarakat tidak mempermasalahkan apakah industri tersebut mencemari lingkungan atau tidak. Sebagian masyarakat yang berkeinginan terlibat dalam pengelolaan dan pemantauan lingkungan tidak mempunyai akses untuk dapat terlibat dalam pelaksanaan pengelolaan dan pemantauan lingkungan (4.) Dorongan untuk melakukan pengelolaan dan pemantauan lingkungan yang dilakukan oleh perusahaan dikarenakan adanya pengawasan 
dari pemerintah maupun untuk meredam protes atau mencegah terjadinya gejolak masyarakat di sekitar lokasi, belum merupakan kesadaran untuk melakukan pengelolaan lingkungan (5.)

Pengawasan yang dilakukan oleh instansi terkait di bidang lingkungan hidup di Kabupaten Kudus masih bersifat pasif dan reaktif, yaitu hanya menunggu pelaporan dari pihak industri dan akan terjun kelapangan apabila terjadi kasus. Pengawasan secara bersama-sama antar Dinas/Instansi terkait belum jelas mekanismenya, sehingga masingmasing instansi belum dapat menjalankan tugas dan fungsinya secara baik (6.)

Dari hasil penelitian di perusahaan, di masyarakat dan Dinas/Instansi diketahui bahwa kelima sampel yaitu PT Djarum Primary Proces 95,3 \% pelaksanaan pengelolaan dan pemantauan lingkungan sudah efektif. PT Pura Nusa Persada 86,6 \% pelaksanaan pengelolaan lingkungan sudah efektif. PT Pura Unit Power Plant 58,6 \% pelaksanaan pengelolaan lingkungan cukup efektif. PT Enggal Subur Kertas < $40 \%$ pelaksanaan pengelolaan lingkungan belum efektif, sedangkan untuk dokumen ANDAL RKL RPL kegiatan Terminal Cargo 68,3 \% pelaksanaan pengelolaan lingkungan cukup efektif. (7.) Belum adanya peraturan daerah yang khusus menangani masalah pengelolaan lingkungan hidup di wilayah Kabupaten Kudus.

Berdasarkan uraian diatas, maka penelitian ini difokuskan dengan mengambil topik "Analisis Dampak Lingkungan Paket Pelebaran Jalan RTA Milono Palangka Raya" akan membahas tentang AMDAL di Paket Pelebaran Jalan RTA Milono Palangka Raya.

\section{METODE PENELITIAN}

Penelitian dillakukan di Paket Pelebaran Jalan RTA Milono Palangka Raya dengan ini mengacu pada diagram alir seperti pada Gambar 1 berikut.

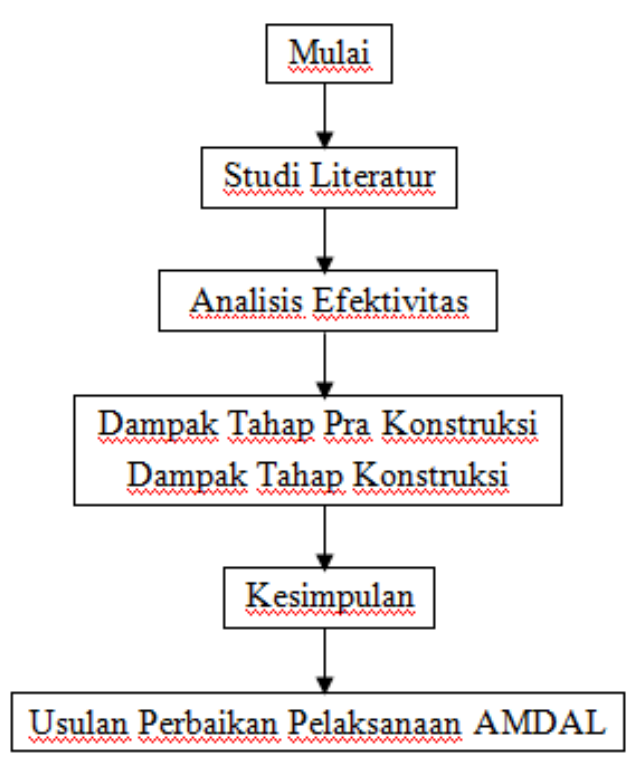

Gambar 1. Diagram Alir Penelitian

\section{HASIL DAN PEMBAHASAN Dampak Pada Tahap Pra Konstruksi}

Kegiatan Paket Pelebaran Jalan RTA Milono Palangka Raya merupakan salah satu paket kegiatan dibawah Pelaksanaan Jalan Nasional Wilayah II Kalimantan Tengah Tahun Anggaran 2014. Kegiatan di paket ini bersumber dari APBN murni dengan kontrak Rp. 24.118.000.000,00 (dua puluh empat milyar seratus delapan belas juta rupiah) yang kontrak pelaksanaannya 232 (dua ratus tiga puluh dua) hari kalender dari 28 April sampai 15 Desember 2014. Adapun penyedia jasa yang diberikan kepercayaan melaksanakan paket ini adalah PT. Sangga Buana Multi Karya pusat Palangkaraya.

PT. Sangga Buana Multi Karya selaku penyedia jasa akan melakukan pekerjaan seperti yang tertuang dalam dokumen kontrak. Dalam dokumen kontrak, bahwa 75 $\%$ adalah pekerjaan aspal yaitu Hot Rolled Sheet Base Leveling (HRS-Base Leveling) dan Hot Rolled Sheet Wearing Course (HRS-WC) sedangkan sisanya $25 \%$ merupakan pekerjaan timbunan biasa, pasangan batu dan box culvert.

Kegiatan pada tahap pra-konstruksi yang sangat potensial menimbulkan dampak terhadap lingkungan (khusus dampak sosial) adalah pembebasan lahan. Dampak pembebasan lahan ini sangat sensitif karena pada umumnya erat kaitannya dengan kelangsungan hidup pemilik lahan terutama 
kalau lahan yang dibebaskan itu berupa areal pemukiman.

Pelaksanan Paket Pelebaran Jalan RTA Milono Palangka Raya memerlukan pembebasan lahan untuk pengerjaan jalan dua jalur sepanjang 3736 meter. Pelaksanaan pembebasan memerlukan penanganan yang seksama karena menyangkut berbagai aspek sosial, ekonomi, dan budaya. Dampak negatif yang mungkin timbul akibat pembebasan antara lain ketidakpastian atas besarnya ganti rugi dan dapat mempengaruhi keterlambatan pelaksanaan.

\section{Dampak Pada Tahap Konstruksi}

Kegiatan pekerjaan umum pada tahap konstruksi biasanya menggunakan alat-alat berat seperti excavator, trailer, truk dan lainlain. Pengoperasian alat berat tersebut mempunyai potensi dampak pada komponen lingkungan fisik seperti :

\section{Peningkatan kebisingan}

Mesin besar tentu juga menghasilkan kebisingan suara yang besar. Hal ini tentu sangat mengganggu lingkungan disekitar areal proyek tersebut. Sumber kebisingan yang lain juga berasal dari pecahan batu atau material akibat lindasan atau akibat penghancuran menggunakan alat berat.

2. Pencemaran udara

Asap mesin alat berat, debu dan asap kendaraan yang macet di lokasi kegiatan merupakan sumber pencemaran udara. Kegiatan masalah ini sudah pasti dialami, bayangkan jika paket berjalan sampai kurun waktu yang lama maka dampak ini juga akan dirasakan selama kurun waktu tersebut.

3. Pencemaran tanah dan air

Tumpahan oli dan solar serta bahan bakar lainnya mencemari tanah juga mencemari air, karena ketika hujan turun tentu oli terserap oleh tanah permukaan juga terbawa oleh air menuju sungai lokasi pembangunan jembatan.

4. Gangguan pada kondisi hidrologi

Kalau air ini sudah tercemar maka kondisi hidrologi terganggu. Ini dapat berdampak buruk bagi kelangsungan yang ada didalamnya. Dampak pada komponen mungkin juga terjadi berupa:
1. Adanya penurunan populasi vegetasi darat akibat kegiatan land clearing.

2. Gangguan dari pencemaran air permukaan.

Dampak pada komponen

lingkungan sosial, ekonomi, dan budaya antara lain :

a. Keterlambatan pengerjaan karena pembebasan lahan

Pengerjaan proyek sempat terhambat karena ada beberapa areal tanah milik warga belum tuntas dibebaskan yang diakibatkan pemilik tanah tidak bersedia tanahnya dibayar dengan nilai ganti rugi yang kecil.

b. Peningkatan kepadatan lalu lintas

Kepadatan lalulintas seperti kemacetan karena adanya aktivitas keluar masuk alat berat, keluar masuk truk pengangkut material dan kegiatan pengukuran ketika pelaksanaan kegiatan.

c. Kerusakan prasarana umum

Adanya prasana umum yang mengalami kerusakan akibat pelaksanaan kegiatan ini antara lain Instalasi kabel listrik PLN, Pipa PDAM, dan Instalasi kabel telkom

Kebisingan peralatan, debu yang timbul akibat pekerjaan tanah berakibat buruk bagi kesehatan warga disekitar tempat pelaksanaan proyek. Banyak penyakit yang bisa timbul akibat aktivitas pembangunan, antara lain gangguan pendengaran, Asma (gangguan saluran pernafasan) dan Iritasi mata karena debu

d. Konflik sosial akibat penggunaan tenaga kerja dari luar lokasi proyek.

Selain peralatan, pengerjaan proyek tentu memerlukan tenaga ahli maupun bukan tenaga ahli (buruh). Pemakaian tenaga kerja dari luar daerah oleh pelaksana (kontraktor) tentu menimbulkan reaksi dari warga sekitar proyek, karena merasa proyek tersebut di daerah mereka kenapa tidak memakai tenaga kerja dari mereka pula. Seperti kegiatan ini, tenaga kerja cenderung lebih banyak dari daerah luar kota Palangka Raya.

Ada beberapa alternatif untuk menghindari atau menanggulangi 
dampak lingkungan pada tahap konstruksi seperti pencegahan teriadi erosi, longsor dan debu, telah dijadikan prosedur keria yang harus dilaksanakn oleh setiap pelaksana kegiatan. Namun dalam pelaksanaan dilapangan hal itu sering diabaikan dengan alasan untuk menghemat biaya pelaksanaan pekerjaan.

\section{KESIMPULAN}

Kegiatan pelebaran jalan di Jalan RTA Milono memiliki dampak pada tahap pra konstruksi dan tahap konstruksi. Kegiatan pada tahap pra-konstruksi yang sangat potensial menimbulkan dampak terhadap lingkungan (khusus dampak sosial) adalah pembebasan lahan. Kegiatan pekerjaan umum pada tahap konstruksi biasanya menggunakan alat-alat berat, sehingga menimbulkan dampak pada komponen lingkungan fisik seperti peningkatan kebisingan, pencemaran udara, tanah dan air, gangguan pada kondisi hidrologi, juga ampak pada komponen lingkungan sosial, ekonomi, dan budaya antara lain keterlambatan pengerjaan karena pembebasan lahan, Peningkatan kepadatan lalu lintas, Kerusakan prasarana umum, dan Konflik sosial akibat penggunaan tenaga kerja dari luar lokasi proyek.

\section{SARAN}

Berdasarkan kesimpulan, maka diperoleh saran sebagai berikut :

1. Untuk pencegahan terjadinya kebisingan, disarankan mengikuti aturan yang ada seperti peredam suara.

2. Membuat aturan atau sanksi dalam menjalankan AMDAL sehingga diharapkan dapat meminimalisir dampak lingkungan.

\section{DAFTAR PUSTAKA}

http://ayuningdia-tantri blogspot.com (diakses 14 Nopember 2014)

http://makalahtekniksipil blogspot.com (diakses 14 Nopember 2014)

Permen Lingkungan Hidup No. 05 Tahun 2012, Jenis Rencana Usaha dan/atau Kegiatan yang wajib memiliki Analisis Mengenai Dampak Lingkungan.

Shoba, A., 2006, Evaluasi Pelaksanaan Pengelolaan dan Pemantauan Lingkungan Pada Beberapa Industri di Kabupaten Tangerang, Tesis, Program Pascasarjana UNDIP, Semarang.

Tias, N. P., 2009, Efektivitas Pelaksanaan AMDAl dan UKP-UPL Dalam Pengelolaan Lingkungan Hidup di Kabupaten Kudus, Tesis, Program Pascasarjana, UNDIP, Semarang. 